\title{
KAJIAN IMPRESIONISTIK PUISI-PUISI KARYA CHAIRIL ANWAR
}

\author{
Hambali $^{1}$ Anzar $^{2}$ \\ Pendidikan Bahasa dan Sastra Indonesia, Universitas Muhammadiyah Makassar \\ hambali.umm@gmail.com \\ Pendidikan Bahasa dan Sastra Indonesia, Universitas Muhammadiyah Makassar \\ anzar.umm@gmail.co.id
}

\begin{abstract}
Abstrac
The main problem in this research is how the image of impressionistic contained in a collection of poems by Anwar based figure of speech, rhyme and diction. This study was a qualitative study in depth about impressionistic based figure of speech, rhyme, and diksi. Data resources was a book of poems by Anwar entitled Aku ini Binatang Jalan. It published by Gramedia Pustaka Utama, in 1986 in Jakarta. Data collection techniques used twofold: (1) the primary data obtained from animal bitch bukuAku It works Anwar who is the object of study in this research. (2) The secondary data in the form of opinions or comments of a critic of literature in books of literature relating to this study. The Results of this study were impresionistik which contained in the poems of Chairil Anwar based of figure speech, rhyme and diction. Majas Metaphor, personification, hyperbole, repetition, and sinekdok were the dominant figure of speech in a poem by Chaeril Anwar )and assonance. Diction used words in everyday life but contains a deep meaning to describe the happiness or sadness.
\end{abstract}

Keywords: impressionistic, romance poetry

\begin{abstract}
Abstrak
Masalah utama dalam penelitian ini yaitu bagaimana gambaran impresionistik yang terdapat dalam kumpulan puisi karya Chairil Anwar berdasarkan majas, rima, dan diksi. Penelitian ini berbentuk deskriptif kualitatif yaitu mengkaji secara mendalam tentang impresionistik berdasarkan majas, rima, dan diksi.Sumber data yaitu buku kumpulan puisi karya Chairil Anwar berjudul Aku Ini Binatang Jalang.Diterbitkan oleh Gramedia Pustaka Utama, pada tahun 1986 di Jakarta. Teknik pengumpulan data yang digunakan ada dua yaitu: (1) Data primer diperoleh dari bukuAku Ini Binatang Jalang karya Chairil Anwar yang merupakan objek kajian dalam penelitian ini. (2) Data sekunder berupa pendapat atau komentar dari kritikus tentang karya sastra dalam buku-buku sastra yang berkaitan dengan penelitian ini. Hasil penelitian ini yaitu impresionistikyang terkandung dalam puisi-puisi karya Chairil Anwarberdasarkan majas, rima, dan diksi. Majas metafora, personifikasi, hiperbola, repetisi, dan sinekdok merupakan majas yang dominan di dalam puisi karya Chairil Anwar bertema percintaan. Rima yang terkandung didominasi oleh rima rangkai, rima silang, aliterasi, dan asonansi. Diksi yang digunakan merupakan kata-kata dalam keseharian tetapi mengandung makna yang dalam untuk menggambarkan kebahagian maupun kesedihan.
\end{abstract}

Kata Kunci: Impresionistik, puisi percintaan 


\section{Pendahuluan}

Sastra menggambarkan kehidupan suatu masyarakat, bahkan menjadi identitas suatu bangsa.Melalui sastra, orang dapat mengenali perilaku dan kepribadian masyarakat serta dapat memahami cermin kehidupan masyarakat.Menurut Wellek dan Warren dalam (Rimang, 2011:1) "Sastra adalah suatu kegiatan kreatif, sederet karya seni", sedangkan menururt Tarigan (1995:3) "Sastra adalah pembayangan atau pelukisan kehidupan dan pikiran imajinatif ke dalam bentuk-bentuk dan struktur-struktur bahasa".

Dunia kesusastraan tidak akan lepas dari karya sastra yang meliputi puisi, novel, cerpen, drama, dan lain-lain. Dari sekian banyak karya sastra, puisi merupakan salah satu karya sastra yang cukup populer di antara karya sastra yang lain, karena dengan puisi seseorang dapat mengungkapkan isi hatinya dalam keadaan senang maupun sedih.Puisi merupakan pengungkapan diri dan jiwa penyair.Di dalamnya ada suasana tertentu dimana seseorang dituntut untuk turut memberikan warna dan kodrat puisi.Puisi diciptakan dalam suasana perasaan yang intens yang menuntut pengucapan jiwa yang spontan dan padat.

Karya sastra puisi diteliti dan dikaji berdasarkan dua unsur yang membangunnya yaitu unsur intrinsik dan ekstrinsik. Unsur intrinsik adalah unsur yang membangun dari dalam sedangkan unsur ekstrinsik adalah unsur yang membangun dari luar. Unsur intrinsik pada puisi adalah irama dan rima, citraan, diksi atau pilihan kata, baris dan bait, tema dan amanat, sedangkan unsur ekstrinsik pada puisi adalah riwayat pengarang kehidupan masyarakat, dan agama.

Puisi sebagai salah satu karya seni sastra dapat dikaji melalui kritik-kritik sastra tertentu.Menurut Wallek dan Austin
(1990:109), kritik sastra adalah studi karya sastra yang konkrit dengan penekanan pada penilaiannya.Kritik sastra adalah ilmu sastra untuk menghakimi karya sastra, untuk memberikan penilaian dan memberikan keputusan bermutu atau tidaknya suatu karya sastra yang sedang dihadapi kritikus.Ada jenis-jenis kritik sastra yang harus diperhatikan, salah satunya melalui kritik sastra menurut pendekatannyayaitu kritik impresionistik.Kritik impresionistik adalah kritik sastra yang meninjau karya sastra berdasarkan kesan-kesan pokok yang ditangkap oleh kritikus atas karya sastra yang dikritiknya.Pengkajian melalui kritik impresionistik yang diterapkan pada puisi-puisi karya Chairil Anwar merupakan suatu hal yang baru bagi peneliti.Melalui kritik impresionistik, pembaca dapat mengekspresikan tanggapan-tanggapannya (impresinya) yang diakibatkan secara langsung oleh karya sastra yang dibacanya.

Menganalisis impresionistik suatu puisi, pembaca harus membaca puisi secara berulang-ulang.Dari kegiatan membaca puisi secara keseluruhan dan secara berulang-ulang itu, maka pembaca dapat merasakan dan mendapatkan gambaran tentang rasa yang terkandung di dalamnya.Berdasarkan uraian tersebut, ditetapkan judul dalam penelitian ini yaitu "Kajian Impresionistik Puisi-PuisiKarya Chairil Anwar".

\section{Metode Penelitian}

\section{a. Desain Penelitian}

Desain yang digunakan dalam penelitian ini ialah pemahaman terhadap hasil-hasil yang berhubungan dengan judul secara maksimal dilanjutkan menjadi studi pustaka, guna mengidentifikasikan pemilihan dan perumusan masalah penelitian, menyusun dan merumuskan hipotesis serta memberikan definisi operasional istilah penelitian, sedangkan langkah berikutnya 
yang dilakukan penulis ialah metode penelitian.

\section{b. Definisi Fokus}

Definisi istilah adalah definisi yang didasarkan atas sifat-sifat yang dapat diamati.

1. Majas adalah cara melukiskan sesuatu dengan jalan menyamakannya dengan sesuatu yang lain.

2. Rima adalah alunan yang tercipta oleh kalimat yang berimbang.

3. Diksi adalah pilihan kata yang tepat untuk mengungkapkan gagasan.

\section{c. Data dan Sumber Data}

Data dalam penelitian ini yaitu kumpulansajak pada puisi-puisi karya Chairil Anwar bertema percintaan.Sumber data dalam penelitian ini yaitu buku kumpulan puisi-puisi karya Chairil Anwar berjudul Aku Ini Binatang Jalang.

d. Teknik Pengumpulan Data

1. Mengumpulkan data melalui penelitian deskriptif kualitatif

2. Mencari sumber-sumber yang relevan dengan masalah yang dikaji. Sumber-sumber tersebut berupa buku, karya ilmiah, dan literatur yang dapat mendukung.

\section{e. Teknik Analisis Data}

Langkah-langkah yang ditempuh dalam menganalisis data yaitu :

1. Membaca berulang-ulang secara cermat puisi-puisi karya Chairil Anwar.

2. Mengidentifikasi dan menjelaskan bentuk puisi berdasarkan kajian impresionistik.

3. Menyimpulkan hasil penelitian tersebut

\section{Hasil Penelitian}

Pada penelitian ini, dikaji sebanyak tiga (3) puisi yang terdapat dalam kumpulan puisi Aku Ini Binatang Jalang karya Chairil Anwar bertema percintaan.

\section{Sajak Putih}

Bersandar pada tari warna pelangi Kau depanku bertudung sutra senja
Di hitam matamu kembang mawar dan melati

Harum rambutmu mengalun bergelut senda

Sepi menyanyi, malam dalam mendoa tiba

Meriak muka air kolam jiwa

Dan dalam dadaku memerdu lagu

Menarik menari seluruh aku terbuka

Hidup dari segala hidupku, pintu

Selama matamu bagiku menengadah Selama kau darah mengalir dari luka Antara kita Mati datang tidak membelah...

\section{1) Majas}

\section{Metafora}

Pada puisi Sajak putih terdapat majas metafora yaitu majas yang mengungkapkan ungkapan secara langsung berupa perbandingan analogis.Berikut larik yang terdapat majas metafora.

"Di hitam matamu kembang mawar dan melati"

Pada larik di atas, mawar dan melati berarti lain, sesuatu yang indah, cinta yang murni dan menggairahkan seperti keindahan bunga mawar (merah) dan melati (putih) yang mekar.Jadi dalam mata si gadis tampak cinta yang tulus, menarik, dan mengikat.

\section{Personifikasi}

Pada puisi Sajak Putih terdapat majas personifikasi yaitu majas yang membandingkan benda-benda tak bernyawa seolah-olah mempunyai sifat seperti manusia.Berikut larik yang terdapat majas personifikasi.

"Sepi menyanyi, malam dalam mendoa tiba"

Pada larik di atas, sepi menyanyi berarti ketika mereka bertemu, mereka tidak saling berbicara.Tidak ada sepatah 
kata yang diucapkan, hanya kata hati yang berkata dan tidak keluar suara.

\section{Repetisi}

Pada puisi Sajak Putih terdapat majas repetisi yaitu majas perulangan kata-kata sebagai penegasan.Berikut majas yang terdapat repetisi.

hidupku, pintu terbuka"

"Hidup dari segala

Pada larik di atas, "Hidup dari segala hidupkuberarti si Aku merasa bahwa hidupnya penuh dengan kemungkinan dan ada jalan keluar.

\section{2) Rima}

\section{Rima Bersilang (a-b-a-b)}

Dikatakan rima bersilang karena bunyi akhir pada larik 1 dan larik 3 memiliki persamaan bunyi, sedangkan larik 2 dan larik 4 pun demikian. Seperti bait di bawah ini.

\section{Bait I}

Bersandar pada tari warna pelangi

Kau depanku bertudung sutra senja

Di hitam matamu kembang mawar dan melati

Harum rambutmu mengalun bergelut senda

Pada bait di atas, bunyi pada akhir larik 1 dan larik 3 memiliki bunyi yang sama yaitu pelangi dan melati, kedua kata ini diakhiri dengan bunyi (i-i). Bunyi pada akhir larik 2 dan larik 4 memiliki bunyi yang sama yaitu senja dan senda, kedua kata ini diakhiri dengan bunyi (a-a).

Bait III

Hidup dari segala hidupku, pintu terbuka

Selama matamu bagiku menengadah

Selama kau darah mengalir dari luka

Antara kita Mati datang tidak membelah...

Pada bait di atas, bunyi pada akhir larik 1 dan larik 3 memiliki bunyi yang sama yaitu terbuka dan luka, kedua kata ini diakhiri dengan bunyi (ka-ka). Bunyi pada akhir larik 2 dan larik 4 memiliki bunyi yang sama yaitu menengadah dan membelah, kedua kata ini diakhiri dengan bunyi (ah-ah).

\section{Rima Rangkai (a-a-b-b)}

Dikatakan rima rangkai karena bunyi akhir pada larik 1 dan larik 2 memiliki persamaan bunyi, sedangkan larik 3 dan larik 4 pun demikian. Seperti bait di bawah ini.

\section{Bait II}

Sepi menyanyi, malam dalam mendoa tiba

Meriak muka air kolam jiwa

Dan dalam dadaku memerdu lagu

Menarik menari seluruh aku

Pada bait di atas, bunyi pada akhir larik 1 dan larik 2 memiliki bunyi yang sama yaitu tiba dan jiwa, kedua kata ini diakhiri dengan bunyi (a-a). Bunyi pada akhir larik 3 dan larik 4 memiliki bunyi yang sama yaitu lagu dan $a k u$, kedua kata ini diakhiri dengan bunyi (u-u).

\section{Aliterasi}

Pada puisi Sajak Putih terdapat aliterasi yaitu perulangan bunyi yang berurutan pada konsonan pada larik tiaptiap awal kata.Seperti di bawah ini.

merupakan aliterasi.

Pada bait I semua larik

"Bersandar pada tari warna pelangi"

"Kau depanku bertudung sutra senja”

"Di hitam matamu kembang mawar dan melati"

"Harum rambutmu mengalun bergelut senda"

Pada bait II larik 1 dan larik 3.

"Sepi menyanyi, malam dalam mendoa tiba"

"Dan dalam dadaku memerdu lagu”

Pada bait III larik 1, 2, dan larik 3. pintu terbuka"

"Hidup dari segala hidupku, menengadah" 


\section{"Selama kau darah mengalir dari luka" \\ Asonansi \\ Pada puisi Sajak Putih terdapat asonansi yaitu perulangan bunyi yang berurutan pada vokal yang menjadi rangka kata, baik pada baris pertama maupun pada baris yang berlawanan. Misalnya: \\ Vokal (a) \\ "Kau depanku bertudung sutra senja” \\ "Harum rambutmu mengalun \\ bergelut senja" \\ Vokal (i) \\ pelangi" \\ "Bersandar pada tari warna}

\section{3) Diksi}

Diksi merupakan makna kiasan yang harus dipahami secara seksama dan menyeluruh, seperti pada bait I, warna pelangi adalah gambaran hati seorang pemuda yang sedang senang, bertudung sutra senja yang dimaksud adalah pada sore hari, di hitam matamu kembang mawar dan melati yang dimaksud adalah bola matanya yang sangat indah. Digambarkan seorang gadis manis sedang duduk di hadapan si Aku. Ia bersandar yang pada ssat itu ada warna pelangi yaitu langit senja yang indah penuh dengan macam-macam warna. Gadis itu bertudung sutra di hari sudah senja sedangkan rambut gadis itu harumditiup angin tampak sedang bersenda gurau, dan dalam mata si gadis yang hitam terlihat bunga mawar dan melati yang mekar.Mawar dan melati yang mekar itu melambangkan sesuatu yang indah dan menarik.Biasanya mawar merah berarti cinta dan melati putih merupakan kesucian.

Pada bait II, sepi menyanyi yang dimaksud adalah tidak ada kata yang keluar hanya rasa sepi yang seakan-akan menyanyi, muka air kolam jiwa yang dimaksud adalah bersedih hati, dadaku memerdu lagu yang dimaksud adalah berkata dalam hati, menari seluruh aku menggambarkan rasa kegembiraan.

Pada bait III, hidup dari hidupku, pintu terbuka menggambarkan bahwa si $\mathrm{Aku}$ merasa hidupnya penuh dengan kemungkinan dan ada jalan keluar, selama matamu bagiku menengadah merupakan kiasan bahwa si gadis masih mencintai si Aku, selama kau darah mengalir dari luka yang dimaksud adalah hidup si Aku penuh harapan selama si gadis masih hidup, antara kita mati datang tidak membelah menggambarkan sampai kematian tiba pun keduanya masih mencintai, dan tidak akan terpisahkan.

\section{Senja Di Pelabuhan Kecil}

Ini kali tidak ada yang mencari cinta di antara gudang, rumah tua, pada cerita

tiang serta temali. Kapal, perahu tiada berlaut

menghembus diri dalam mempercaya mau berpaut

Gerimis mempercepat kelam. Ada juga kelepak elang

menyinggung muram, desir hari lari berenang

menemu bujuk pangkal akanan.

Tidak bergerak

dan kini tanah dan air tidur hilang ombak

Tiada lagi.Aku sendiri. Berjalan

menyisir semenanjung, masih pengap harap

sekali tiba di ujung dan sekalian selamat jalan

dari pantai keempat, sedu penghabisan bisa terdekap.

\section{1) Majas}

\section{Metafora}

Pada puisi Senja di Pelabuhan Kecil terdapat majas metafora yaitu majas yang mengungkapkan ungkapan secara langsung berupa perbandingan analogis. 
Berikut larik yang terdapat majas metafora.

"di antara gudang, rumah tua, pada cerita tiang serta temali"

"Kapal, perahu tiada berlaut"

"tanah dan air tidur"

Pada larik di atas, penyair menggunakan bahasa kias untuk memperdalam rasa duka yang dirasakan. Ketidakberdayaan diungkapkan penyair sebagai sebuah gudang, rumah tua, tiang dan temali yang tiada berguna.Harapan penyair kandas bagai kapal dan perahu yang tidak melaut karena menghempaskan diri di pantai saja.Serta kebekuan hati yang dirasakan penyair bagai air dan tanah yang tidur dan tidak bergerak.

\section{Personifikasi}

Pada puisi Senja di Pelabuhan Kecil terdapat majas personifikasi yaitu majas yang membandingkan benda-benda tak bernyawa seolah-olah mempunyai sifat seperti manusia.Berikut larik yang terdapat majas personifikasi.

"Ada juga kelepak elang menyinggung muram, desir hari lari berenang"

"dan kini tanah dan air tidur hilang ombak"

"sedu penghabisan bisa terdekap"

Pada larik di atas, diungkapkan penyair melalui "Ada juga kelepak elang menyinggung muram, desir hari lari berenang dan kini tanah dan air tidur hilang ombak dan sedu penghabisan bisa terdekap". Lewat kata-kata tersebut, penyair mencoba menghidupkan kelepak elang yang mampu menyinggung perasaan orang yang sedang muram.Hari pun dikatakan penyair seakan berlari dan berenang menjauh hingga penyair bisa memutar balik waktu itu.Penyair juga berusaha menidurkan tanah dan air sehingga merasa dalamlah kebekuan hati seseorang yang digambarkan.

\section{Sinekdok}

Pada puisi Senja di Pelabuhan Kecil terdapat majas sinekdok yaitu majas yang menyebutkan bagian untuk menggantikan benda secara keseluruhan atau sebaliknya. Berikut larik yang terdapat majas sinekdok.

"tiang serta temali. Kapal, perahu tiada berlaut"

Pada larik di atas, terlihat kata tiang yang sebenarnya penyair mencoba menggambarkan rumah.Kata kapal dan perahu yang berarti pelabuhan.

\section{Hiperbola}

Pada puisi Senja di Pelabuhan Kecil terdapat majas hiperbola yaitu majas yang berupa pernyataan berlebihan dari kenyataannya dengan maksud memberikan kesan mendalam atau meminta perhatian. Berikut larik yang terdapat majas hiperbola.

"dan kini tanah dan air tidur hilang"

"dari pantai keempat, sedu penghabisan bisa terdekap"

Pada larik di atas, hiperbola terdapat pada kalimat dan kini tanah dan air tidur hilang serta dari pantai keempat, sedu penghabisan bisa terdekap melebihlebihkan kebekuan hati karena si gadis itu.

\section{2) Rima}

\section{Rima Rangkai (a-a-b-b)}

Dikatakan rima rangkai karena bunyi akhir pada larik 1 dan larik 2 memiliki persamaan bunyi, sedangkan larik 3 dan larik 4 pun demikian. Seperti bait di bawah ini.

\section{Bait I}

Ini kali tidak ada yang mencari cinta di antara gudang, rumah tua, pada cerita tiang serta temali. Kapal, perahu tiada berlaut menghembus diri dalam mempercaya mau berpaut

Pada bait di atas, bunyi pada akhir larik 1 dan larik 2 memiliki bunyi yang sama yaitu cinta dan cerita, kedua kata ini diakhiri dengan bunyi (ta-ta). Bunyi pada akhir larik 3 dan larik 4 memiliki bunyi yang sama yaitu berlaut dan berpaut, 
kedua kata ini diakhiri dengan bunyi (utut).

\section{Bait II}

Gerimis mempercepat kelam. Ada juga kelepak elang menyinggung muram, desir hari lari berenang menemu bujuk pangkal akanan. Tidak bergerak dan kini tanah dan air tidur hilang ombak

Pada bait di atas, bunyi pada akhir larik 1 dan larik 2 memiliki bunyi yang sama yaitu elang dan berenang, kedua kata ini diakhiri dengan bunyi (ang-ang). Bunyi pada akhir larik 3 dan larik 4 memiliki bunyi yang sama yaitu bergerak dan ombak, kedua kata ini diakhiri dengan bunyi (ak-ak).

Rima Bersilang (a-b-a-b)

Dikatakan rima bersilang karena bunyi akhir pada larik 1 dan larik 3 memiliki persamaan bunyi, sedangkan larik 2 dan larik 4 pun demikian. Seperti bait di bawah ini.

Bait III

Tiada lagi.Aku sendiri.

Berjalan harap

menyisir semenanjung, masih pengap

sekali tiba di ujung dan sekalian selamat jalan

dari pantai keempat, sedu penghabisan bisa terdekap.

Pada bait di atas, bunyi pada akhir larik 1 dan larik 3 memiliki bunyi yang sama yaitu berjalan dan jalan, kedua kata ini diakhiri dengan bunyi (an-an). Bunyi pada akhir larik 2 dan larik 4 memiliki bunyi yang sama yaitu harap dan terdekap kedua kata ini diakhiri dengan bunyi (ap-ap).

\section{Aliterasi}

Pada puisi Senja di Pelabuhan Kecil terdapat aliterasi yaitu perulangan bunyi yang berurutan pada konsonan pada larik tiap-tiap awal kata.Seperti di bawah ini.

Pada bait I larik 3 dan larik 4.

"tiang serta temali. Kapal, perahu tiada berlaut" "menghembus diri dalam
mempercaya mau berpaut"
Pada bait II larik 2.
"menyinggung muram, desir hari lari berenang"

Pada bait III larik 2 dan larik 4.

"menyisir semenanjung, masih pengap harap"

"dari pantai keempat, sedu penghabisan bisa terdekap."

\section{Asonansi}

Pada puisi Senja di Pelabuhan Kecil terdapat asonansi yaitu perulangan bunyi yang berurutan pada vokal yang menjadi rangka kata, baik pada baris pertama maupun pada baris yang berlawanan. Misalnya:

Vokal (a)

"di antara gudang, rumah tua, pada cerita".

Vokal (i)

"Tiada lagi.Aku sendiri.Berjalan".

Vokal (e)

"Gerimis mempercepat kelam.Ada juga kelepak elang".

\section{3) Diksi}

Pilihan kata dalam puisi ini terlihat biasa dan terkesan kata-kata yang digunakan dalam kesehariannya.Tetapi arti katanya bukan arti yang sebenarnya.Walaupun dengan kata-kata yang biasa tapi penyair memberikannya sebagai kata-kata yang mengandung makna konotasi. Pada bait I seperti kata gudang, rumah tua pada cerita, tiang serta temali, kapal dan perahu yang tidak berlaut, kata-kata ini bermakna ungkapan perasaan sedih dan sepi. Penyair merasakan kehampaan hati karena cintanya yang hilang.Kenangan cinta sangat memukul hatinya sehingga hatinya mati setelah orang yang dicintainya pergi.Bagi penyair, gudang dan rumah tua dianggap sebagai sesuatu yang tak berguna seperti dirinya yang dianggap tiada berguna lagi. Kata mempercaya mau berpaut itu sebenarnya juga berarti harapan penyair akan kekasihnya. 
Bait II penyair memfokuskan perhatian pada suasana pelabuhan dan tidak lagi pada benda-benda di pelabuhan yang beraneka ragam. Gerimis yang mempercepat kelam berarti kesedihan yang dirasakan penyair semakin bertambah.Ada juga kelepak elang yang menyinggung muram menggambarkan hati penyair dibuat lebih sedih.Pilihan kata seperti kelam dan muram memberi kesan pada makna kesedihan yang dirasakan. Desir hari lari berenang mengartikan harapan penyair telah hilang. Kata menemu bujuk pangkal akanan merupakan ungkapan harapan terakhir penyair.Kata tanah dan air yang tidur juga menyatakan suatu kebekuan.

Bait III pikiran penyair lebih dipusatkan pada dirinya dan bukan pada pantai dan benda-benda sekitar pantai itu. Kata $A k u$ sendiri berarti tidak ada lagi yang diharapkan akan memberikan hiburan dalam kesendirian dan kedukaannya itu. Dalam kesendirian itu, penyair berjalan menyisir semenanjung merupakan perjalanan dengan dipenuhi harapan. Setelah penyair mencapai ujung tujuan, ternyata orang yang diharapkan akan menghiburnya itu malah mengucapkan selamat jalan. Penyair merasa bahwa sama sekali tidak ada harapan untuk mencapai tujuannya. Karena itu dalam kesendirian dan kedukaannya, pengarang merasakan dari pantai keempat, sedu penghabisan bisa terdekap menggambarkan betapa mendalam rasa sedihnya itu, ternyata dari pantai keempat sedu sedan tangisnya dapat dirasakan.

Penyair mampu mengolah pilihan katanya sebaik mungkin walaupun dengan bahasa percakapan tapi mampu menghadirkan makna yang dalam.Hanya ada satu kata yang tidak biasa diucapkan dalam kehidupan sehari-hari yaitu akanan.

\section{Cintaku Jauh Di Pulau}

Cintaku jauh di pulau,

Gadis manis sekarang iseng sendiri.

Perahu melancar, bukan memancar,

Di leher kukalungkan ole-ole buat si pacar. terasa

Angin membantu, laut terang, tapi

Aku tidak 'kan sampai padanya.

Di air yang tenang, di angin mendayu, melaju

Di perasaan penghabisan segala

Ajal bertakhta, sambil berkata: saja."

"tujukan perahu ke pangkuanku

Amboi! Jalan sudah bertahun kutempuh!

Perahu yang bersama 'kan merapuh!

Mengapa ajal memanggil dulu

Sebelum sempat berpeluk dengan cintaku?!

Manisku jauh di pulau, sendiri.

Kalau ' $\mathrm{ku}$ mati, dia mati iseng

\section{1) Majas}

\section{Personifikasi}

Pada puisi Cintaku Jauh di Pulau terdapat majas personifikasi yaitu majas yang membandingkan benda-benda tak bernyawa seolah-olah mempunyai sifat seperti manusia.Berikut larik yang terdapat majas personifikasi.

"Angin membantu, laut terang, tapi terasa"

"Di air yang tenang, di angin mendayu,"

"Mengapa ajal memanggil dulu"

Pada larik di atas, angin membantu, laut terang berarti alam turut membantu si Aku agar bisa segera bertemu dengan si gadis.Terpaan angin membuat perahu si Aku melaju dengan cepat dibantu dengan cahaya terang dari laut.Air yang tenang, angin mendayumenggambarkan bahwa 
perasaan si Aku mulai mengalami kesedihan karena khawatir tidak dapat berjumpa dengan kekasihnya. Mengapa ajal memanggil dulu menceritakan hidupnya telah berakhir sebelum sampai pada tujuannya bertemu si gadis.Kematian telah lebih dulu datang dibandingkan kedatangannya untuk berjumpa dengan kekasihnya.

\section{Hiperbola}

Pada puisi Cintaku Jauh di Pulau terdapat majas hiperbola yaitu majas yang berupa pernyataan berlebihan dari kenyataannya dengan maksud memberikan kesan mendalam atau meminta perhatian. Berikut larik yang terdapat majas hiperbola.

"Amboi!Jalan sudah bertahun kutempuh!"

"Perahu yang bersama "kan merapuh!"

"Kalau "ku mati, dia mati iseng sendiri".

Pada larik di atas, jalan sudah bertahun kutempuhmemberikan kesan berlebihan dalam perjalanan untuk bertemu dengan kekasihnya.Perahu yang bersama 'kan merapuh seolah-olah perahu yang membawanya dalam perjalanan panjang akan segera rusak di tengah perjalanan.Kalau ' $k u$ mati, dia mati iseng sendirimenggambarkan kekhawatiran yang sangat dalam jika kekasihnya akan mati sia-sia dalam penantian jika si Aku telah lebih dulu mati.

\section{2) Rima \\ Rima Bersilang (a-b-a-b)}

Dikatakan rima bersilang karena bunyi akhir pada larik 1 dan larik 3 memiliki persamaan bunyi, sedangkan larik 2 dan larik 4 pun demikian. Seperti bait di bawah ini.

\section{Bait I}

Cintaku jauh di pulau, sendiri.

Gadis manis sekarang iseng

Bait V

Manisku jauh di pulau, sendiri.

Kalau 'ku mati, dia mati iseng

Pada bait di atas, bunyi pada akhir larik 1 bait $\mathrm{I}$ dan larik 1 bait $\mathrm{V}$ memiliki bunyi yang sama yaitu pulau dan pulau, kedua kata ini diakhiri dengan bunyi (auau). Bunyi pada akhir larik 2 bait Idan larik 2 bait $\mathrm{V}$ memiliki bunyi yang sama yaitu sendiri dan sendiri kedua kata ini diakhiri dengan bunyi (ri-ri).

\section{Rima Rangkai (a-a-b-b)}

Dikatakan rima rangkai karena bunyi akhir pada larik 1 dan larik 2 memiliki persamaan bunyi, sedangkan larik 3 dan larik 4 pun demikian. Seperti bait di bawah ini.

\section{Bait II}

Perahu melancar, bukan memancar,

Di leher kukalungkan ole-ole buat si pacar.

Angin membantu, laut terang, tapi terasa

Aku tidak 'kan sampai padanya.

Pada bait di atas, bunyi pada akhir larik 1 dan larik 2 memiliki bunyi yang sama yaitu memancar dan pacar, kedua kata ini diakhiri dengan bunyi (car-car). Bunyi pada akhir larik 2 dan larik 4 memiliki bunyi yang sama yaitu terasa dan padanya kedua kata ini diakhiri dengan bunyi (a-a).

Bait III

Di air yang tenang, di angin mendayu, melaju

Di perasaan penghabisan segala

Ajal bertakhta, sambil berkata: saja."

"tujukan perahu ke pangkuanku

Pada bait di atas, bunyi pada akhir larik 1 dan larik 2 memiliki bunyi yang sama yaitu mendayu dan melaju, kedua kata ini diakhiri dengan bunyi (u-u). Bunyi pada akhir larik 2 dan larik 4 memiliki bunyi yang sama yaitu berkata 
dan saja kedua kata ini diakhiri dengan bunyi (a-a).

Bait IV

Amboi! Jalan sudah bertahun kutempuh!

Perahu yang bersama 'kan merapuh!

Mengapa ajal memanggil dulu

Sebelum sempat berpeluk dengan cintaku?!

Pada bait di atas, bunyi pada akhir larik 1 dan larik 2 memiliki bunyi yang sama yaitu kutempuh dan merapuh, kedua kata ini diakhiri dengan bunyi (puh-puh). Bunyi pada akhir larik 2 dan larik 4 memiliki bunyi yang sama yaitu dulu dan cintaku kedua kata ini diakhiri dengan bunyi (u-u).

\section{Aliterasi}

Pada puisi Cintaku Jauh di Pulau terdapat aliterasi yaitu perulangan bunyi yang berurutan pada konsonan pada larik tiap-tiap awal kata.Seperti di bawah ini.

Pada bait I larik 1.

"Cintaku jauh di pulau,"

Pada bait II larik 1.

"Perahu melancar, bukan memancar,"

Pada bait III larik 2 dan larik 4. melaju”

"Di perasaan penghabisan segala saja."

"tujukan perahu ke pangkuanku

Pada bait IV larik 2 dan larik 4.

"Perahu yang bersama "kan merapuh!"

"Sebelum sempat berpeluk dengan cintaku?!"

Pada bait V larik 1.

"Manisku jauh di pulau,"

\section{Asonansi}

Pada puisi Cintaku Jauh di Pulau terdapat asonansi yaitu perulangan bunyi yang berurutan pada vokal yang menjadi rangka kata, baik pada baris pertama maupun pada baris yang berlawanan. Misalnya:

Vokal (a)

"Ajal bertakhta, sambil berkata".

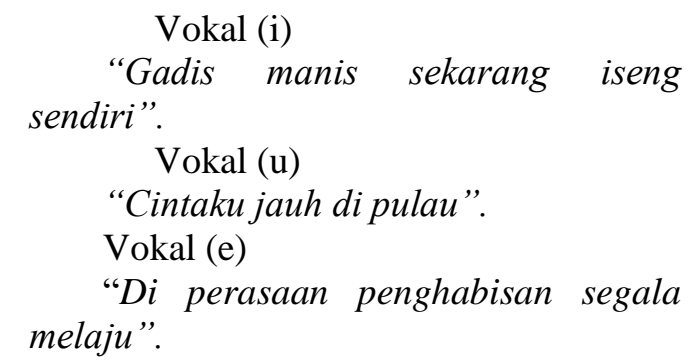

\section{3) Diksi}

Pilihan kata pada puisi Cintaku Jauh di Pulau merupakan kata-kata yang umum digunakan.Kata-kata tersebut terkesan biasa tetapi makna yang terkandung dalam rangkaian kata-kata tersebut tidaklah biasa dan sederhana.Kesedihan dan kekhawatiran terwakilkan oleh penggunaan kata yang tergolong biasa. Pada bait I "Cintaku jauh di pulau" berarti kekasih tokoh Aku (gadis manis) berada di suatutempat yang jauh. "Gadis manis sekarang iseng sendiri" merupakan sang kekasih tersebut adalahseorang gadis manis yang menghabiskanwaktu sendirian (iseng) tanpa kehadiran tokoh Aku.

Pada bait II, si tokoh aku menempuhperjalanan jauh dengan perahu karena inginmenjumpai atau menemui kekasihnya tercermin dari kata perahu melancar. Ketika itucuaca sangat bagus dan malam terang ketika bulanbersinar, namun hati si aku merasa gundahkarena rasanya ia tak akan sampai padakekasihnya.

Bait III menceritakan perasaan si Akuyang semakin sedih karena walaupun air tenang, angin mendayu, tetapi pada perasaannya ajaltelah memanggilnya (Ajal bertahta sambil berkata: "Tujukan perahu ke pangkuanku saja”). Kesedihan yang dialami si Aku semakin besar karena ajal akan menjemput dalam perjalanannya mengarungi lautan untuk bisa bertemu dengan si gadis manis.

Bait IV menunjukkan si Aku putus asa.Demi menjumpai kekasihnya ia telah bertahun-tahun berlayar, bahkan perahu yangmembawanya akan rusak, namun ternyatakematian menghadang dan 
mengakhiri hidupnyaterlebih dahulu sebelum ia bertemu dengankekasihnya. Kata sebelum sempat berpeluk dengan cintaku menggambarkan rasa kecewa yang begitu dalam dirasakan oleh si Aku karena pengorbanannya untuk bertemu sang kekasih akan sia-sia direnggut oleh ajal.

Bait V merupakan kekhawatiran si tokoh Aku tentang kekasihnya, bahwa setelah ia meninggal, kekasihnya itu akan mati jugadalam penantian yang sia-sia.

\section{Simpulan}

Berdasarkan hasil penelitian dan pembahasan pada kumpulan puisi " $A k u$ Ini Binatang Jalang” karya Chairil Anwar bertema percintaan khususnya dalam majas, rima, dan diksi, maka penulis dapat menarik simpulan sebagai berikut:

1. Puisi-puisi karya Chairil Anwar dalam bukunya berjudul " $A k u$ Ini Binatang Jalang" banyak mengandung majas. Majas yang paling dominan yaitu majas personifikasi, metafora, hiperbola, sinekdok dan repetisi.

2. Puisi-puisi karya Chairil Anwar dalam bukunya berjudul "Aku Ini Binatang Jalang" tersusun atas rima rangkai, rima bersilang, aliterasi, dan asonansi.

3. Puisi-puisi karya Chairil Anwar dalam bukunya berjudul "Aku Ini Binatang Jalang” banyak menggunakan diksi yang berfungsi untuk memberi unsur puitis dan menambah keindahan bunyi sehingga puisi tidak terasa monoton.

\section{Daftar Rujukan}

Rimang, Siti Suwadah. 2011. Kajian Sastra Teori dan Praktik. Yogyakarta: Aura Pustaka.

Tarigan, Henry Guntur. 1985. Prinsip-prinsip Dasar Sastra. Bandung: Angkasa.
Wellek, Rane and Austin Warren. 1990. (Terjemahan Melani Budianta) Teori Kesusastraan. Jakarta: Gramedia. 